Max-Planck-Institut für demografische Forschung

Max Planck Institute for Demographic Research

Doberaner Strasse 114 - D-18057 Rostock - GERMANY

Tel +49 (0) 3812081 - 0; Fax +49 (0) 3812081 - 202;

http://www.demogr.mpg.de

MPIDR WORKING PAPER WP 2002-037

AUGUST 2002

\title{
Does Economic Uncertainty Have an \\ Impact on Decisions to Bear Children? Evidence from Eastern Germany
}

Sumon Kumar Bhaumik (sbhaumik@london.edu)

Jeffrey B. Nugent

This working paper has been approved for release by: Alexia Fürnkranz-Prskawetz

(fuernkranz@demogr.mpg.de), Head of the Research Group on Population, Economy, and Environment.

(C) Copyright is held by the authors.

Working papers of the Max Planck Institute for Demographic Research receive only limited review.

Views or opinions expressed in working papers are attributable to the authors and do not necessarily reflect those of the Institute. 


\title{
Does Economic Uncertainty Have an Impact on Decisions to Bear Children? Evidence from Eastern Germany ${ }^{*}$
}

\author{
Sumon Kumar Bhaumik ${ }^{* *}$ \\ London Business School \\ Jeffrey B. Nugent \\ University of Southern California
}

\begin{abstract}
:
Economic agents routinely face various types of economic uncertainty. Seldom have these various forms of uncertainty manifested themselves more sharply than in the transition economies of Central and Eastern Europe. In East Germany, the transition was especially rapid and sharp since East Germany virtually over night made the transition from the Eastern European system to the market economy of Western Germany. Uncertainties increased and many institutional and behavioral adjustments took place in a concentrated period of time. Among the latter was a sharp fall in fertility rates, leading to a growing literature on the explanation for this decline. This paper focuses directly on the link between uncertainty and childbearing decisions and examines the link at the micro level. It develops a stylized overlapping generations model showing that the relationship between economic uncertainty and childbearing decisions is not necessarily monotonic, and hence that the aforementioned inverse relationship is merely a testable hypothesis. It then uses GSOEP data for 1992 and 1996 to estimate the nature of this relationship, and concludes that while this relationship was indeed negative for East German women during these two years, the nature of uncertainty affecting their childbearing decisions differed across the years.
\end{abstract}

JEL classification: D1, D81, J13, J22, P36

July 2002

\footnotetext{
* The paper was written with support from Max Planck Institute for Demographic Research, Rostock, Germany. The authors would like to thank Alexia Prskawetz, Michaela Kreyenfeld, T. Paul Schultz, Ira Gang and attendants at the Population Association of America Annual Meeting in Atlanta in May 2002 for their comments on earlier versions of the paper, Cheng Hsiao for providing advice about econometric techniques, and DIW, Berlin for making available the GSOEP data.

** Corresponding author. Centre for New and Emerging Markets, London Business School, Sussex Place, Regent's Park, London NW1 4SA, UK, Phone: +44 20 7262-5050, extension 3386, Fax: +44 20 7724-8060, Email: sbhaumik@london.edu
} 


\section{Introduction}

Economic agents routinely face various types of economic uncertainty. As producers they may be uncertain about future quantities (such as production risk) or prices (price risk). As workers, they may be uncertain about the likelihood of finding employment or about the wage rates that they will obtain should they be employed. They also may be uncertain about their physical ability to work (in the face of disability and old age). As investors, they may be uncertain about rates of return and their ability to accumulate assets. As parents they may be uncertain about their ability to supervise and care for their children. Many economic agents face several of these uncertainties at the same time.

In the context of developing countries that generally lack insurance markets for dealing with any of these sources of uncertainty, but where the uncertainties are many and serious, Leibenstein (1957) and Cain (1980, 1981, 1983) argued that the presence of children tended to reduce all the relevant forms of uncertainty, thereby elevating uncertainty to primary position as an explanation for why fertility rates are so high in these countries, and especially in rural areas thereof.

The socialist societies of Central and Eastern Europe introduced many institutional mechanisms for reducing such uncertainties. They provided generous social security programs, virtually universal employment possibilities backed up by a statutory right to work, universal health insurance, a generous maternity leave program, child care centres at places of employment, food subsidies, rent subsidies and price controls on virtually everything. Income differentials were remarkably small, except perhaps between the masses and members of the nomenklatura. By the mid-1980s, total fertility rates in these countries averaged about 2.0, with East Germany, Hungary and Czechoslovakia somewhat below the average and Estonia, Romania and Poland slightly above it.

The transition in such economies from centrally planned to market economies, therefore, has implied very large increases in uncertainty since the transition required many of these uncertainty-reducing institutions to be dismantled. On top of this was considerable lack of familiarity with market mechanisms and how to take advantage of them. Nowhere was this transition as abrupt as in Eastern Germany, the former German Democratic Republic (GDR), due to its immediate reunification with the Federal Republic of Germany (West Germany). 
Prior to unification a little over a decade ago, the total fertility rate in the former GDR was higher than that in West Germany (1.7. compared to 1.4). However, soon after the unification of East and West Germany, the East German fertility rate declined sharply to the West German level and then beyond it, indeed to 0.8 by 1995 (compared to the West German rate that remained at about 1.4) before climbing up again to almost 1.2 by 1998 (Stortzbach, 1995; Kreyenfeld, 2000a). Indeed, in at least one East German state, by the time the trough in fertility was reached in the mid-1990s, the number of births was less than a third what it had been before unification. Ranjan (1999) quotes one demographer as characterizing the dramatic decline in East German fertility as "comparable to those in war, plague or famine, and has been attributed in large part to economic uncertainty."

Certainly, it is plausible that the uncertainties identified at the beginning of this paper increased substantially after unification and remained high for some time, some, such as fear of unemployment and financial uncertainty, more than others. Yet, in view of the arguments made by Cain and Leibenstein, this could imply an increase in fertility rather than a reduction in fertility. Yet, for Leibenstein at least, the emphasis was on old age uncertainty. For income or employment security in the short run, the effect could be just the opposite as the presence of young children could reduce mobility and the ability to search for work and hence to reduce the probability of employment. Could such increased job and financial uncertainty have translated into such a sharp reduction in fertility? Witte and Wagner (1995) and Adler (1997) hinted that this could be the case. Ranjan (1999), assuming this to be the case, constructed a theoretical model that showed an increase in income uncertainty could cause a temporary reduction in fertility. While he showed the result of his model to be rather robust to different specifications, he presented neither simulations showing plausible magnitudes of the effect nor any empirical evidence.

This seems plausible for income uncertainty. But would this hold for all forms of uncertainty? Which form of uncertainty should have the greatest effect on fertility? Which form increased the most and which may have gradually fallen by the late 1990s? 
Moreover, while uncertainties of various sorts were increasing, other factors relevant to fertility may also have been changing. Real income fell, ${ }^{1}$ and the accessibility and cost of education, housing, and health care also changed. Wage rates of both women and men were affected. Whereas previously there had been virtually no part-time employment opportunities for women, after unification there were many (Kreyenfeld, 2000b). Training subsidies were introduced to reduce the foreseen mismatch between the supply and demand for different skills in the labour market. Any of these other changes, therefore, could have accounted for the rather remarkable post-unification changes in the fertility behaviour of East German women. In order to isolate the effects of uncertainties of various sorts from these other influences, therefore, it is necessary both to construct plausible measures of the different types of uncertainty and to control for several of these other factors.

To date, there is neither a theoretical model that distinguishes between the various kinds of uncertainty nor an empirical test of the effects of any such form on fertility in the East German context. Instead, existing explanations for the fertility decline in transition economies have taken the following forms: (1) interpreting it as a temporary one arising from the postponement of the first birth, and therefore merely a change in the spacing of children from early to later years (Witte and Wagner, 1995); (2) the neoclassical economic model, tying the greater fertility decline either to a dramatic rise in female wage rates coupled with the decline in subsidized child care services (Hunt, 1997; Micevska, 2001) or to a sharp fall in real income with "subsistence" consumption held constant (Micevska and Zak, 2002), and (3) a sociological model in which the attitudes of East German women changed in such a way as to emulate those of West German women (Stortzbach, 1995).

The purpose of this paper is to test the impact of economic uncertainty on childbearing decisions, after distinguishing between alternative sources of uncertainty. It uses the East German segment of the German Socio-economic Panel (GSOEP) for testing the hypothesis that uncertainty affects fertility adversely. The main advantage of the GSOEP is that it contains responses to rather unusual questions on fears and uncertainties of various kinds that can be used to construct indexes of each of these several different kinds of uncertainty.

\footnotetext{
1 Indeed, Micevska and Zak (2002) argue that it is the temporary fall in income below subsistence consumption requirements that has caused the decline in fertility in the transition economies. They provide some evidence but it is primarily cross-country analysis at the macroeconomic level.
} 
The presentation is as follows. Section II presents a simple overlapping generations model that is used to highlight the complex and non-linear relationship between uncertainty and fertility. Section III presents the data and the measures of uncertainty used in the empirical analysis. The regression results are presented in Section IV. Section V concludes.

\section{The Model}

Suppose that a representative parent lives for three periods. During period I, she is young, and is taken care of by her parents. At the beginning of period II, she has a partner, and has to take three decisions: (1) the number of children, (2) the extent of labour force participation, and (3) the amount of savings for old age. During period II, she works, earns, consumes, takes care of her children and saves for old age. In period III, she is old and does not work, making her consumption dependent on the principal and earned interest amount of her savings in period II, and the interest payments thereof, and transfers from private or public sources. At the end of period III, the representative woman dies.

The utility of a representative parent depends on her own consumption and leisure, as well as on the future consumption of her children. She cannot form accurate expectations about the future decisions of her children, and hence focuses on the one aspect of their life as economic agents about which she can form some expectations, namely, their income. Hence, the utility function of the parent who is assumed to "care" for her children can be given by

$$
U^{P}=U\left(C_{I I}^{P}, l\right)+\rho U\left(C_{I I I}^{P}, \bar{T}\right)+\rho n V\left(I_{I I I}^{k}\right)
$$

where $C$ is consumption, $l$ is leisure, $n$ is the number of children, $I$ is income, and $\rho$ is time discount factor. The superscripts $P$ and $k$ indicate the representative parent and child respectively.

A representative parent faces two constraints: a time constraint, and a budget constraint. The time constraint is given by

$$
\bar{T}=t_{w}+t_{k}(n)+l, \quad t_{K}^{\prime}>0, t_{K}^{\prime \prime}<0
$$

where $t_{k}$ is the time allotted to child care, and $t_{w}$ is the time devoted to work. This constraint can be rewritten as

$$
l=\bar{T}-t_{w}-t_{k}(n)
$$

Her wage rate $w_{p}$ depends on the human capital with which, at the beginning of period II, she is already endowed. Hence, at that point of time, her wage rate is pre-determined. The budget constraint for the parent for period II, therefore, is given by

$$
t_{w} \bar{w}_{p}=C_{I I}^{P}+S^{P}+p_{H} q(n) n \quad q^{\prime}(n) \leq 0
$$


where $S^{P}$ is the amount that the representative woman saves for her old age consumption, $p_{H}$ is the price per unit of human capital, $n$ is the number of children that she has, and $q(n)$ is the amount of human capital the woman wants to "buy" for each of the children. It is assumed that the human capital that each child can be endowed with varies inversely with the number of children, i.e., there is a trade-off between the quantity and quality of children. This constraint can be rewritten as

$$
C_{I I}^{P}=t_{w} \bar{w}_{p}-S^{P}-p_{H} q(n) n
$$

In a society in which help from children in old age is largely limited to emotional support, we assume that the budget constraint of a parent in period III would be given by

$$
(1+\bar{r}) S^{P}+B=C_{I I I}^{P}
$$

where $B$ is the amount of old age benefits that a parent expects to receive from the government. Since the parent in this model is able to determine the human capital endowment of her children, she treats the future wage rate of the children as endogenous. For lack of better information, the parent also assumes, that a child would work an institutionally fixed number of hours per time period. Hence, the income of a child in period III and which enters the parent's utility function is given by

$$
\bar{t}_{w} w^{k}(q)=I_{I I I}^{k}
$$

Hence, the utility function of a representative parent can be rewritten as

$$
U^{P}=U\left(t_{w} \bar{w}_{p}-S^{P}-p_{H} q(n) n, \bar{T}-t_{w}-t_{k}(n)\right)+\rho U\left((1+\bar{r}) S^{P}+B\right)+\rho n V\left(\bar{t}_{w} w^{k}(q)\right)[1 \mathrm{a}]
$$

The optimisation program of a representative parent, therefore, is to maximize $U^{P}$ with respect to the three choice variables: number of children $(n)$, extent of labour force participation $\left(t_{w}\right)$, and amount saved in period II for period III consumption $\left(S^{P}\right)$. Since the use of a concave utility function would assure interior solutions, the optimal values of the choice variables can, in principle, be numerically obtained from the first order conditions, given the values of the model's parameters. However, since the utility function, and the resultant first order conditions are highly non-linear, it is computationally expensive, sometimes even impossible, to obtain numerical convergence to unique meaningful solutions. Hence, we attempt simulations with a simpler version of the model, one in which a parent has only one choice variable, namely, the number of children $(n)$. In other words, both the labour supply $\left(t_{w}\right)$ and the amount saved for old age consumption $\left(S^{P}\right)$ are held exogenous. ${ }^{2}$

Even though the representative parent may face uncertainties about such different concerns as employment, wage rates, health, childcare, etc., all such forms of uncertainty could be interpreted as affecting her decisions through their impact, direct or indirect, on her expected

\footnotetext{
${ }^{2}$ Specifically, the representative parent is assumed to work an institutionally fixed number of hours, indicating inflexibility in labour contracts in that the choice of working is limited to (say) 0,20 or 40 hours a week, and to save a fixed proportion of her income for old age consumption.
} 
income. It is easy to see how uncertainties regarding employment and wage rates can affect expected income. In other cases, the causal connection may be more subtle. For example, uncertainty regarding affordable and adequate childcare facilities would impact the expected income of the parent by way of the number of hours she is able to work per week after taking care of her children, perhaps only 20 instead of 40 hours (see footnote 2). Hence, for the simulations, we proxy all forms of uncertainty with a generic "job related" uncertainty which has an impact on the expected income of the representative individual.

To capture this job-related uncertainty, we introduce a parameter $\mu$ as the probability that a parent would remain employed during period II. Hence, $t_{w}$ in equation (1a) would be replaced by $\mu . t_{w}{ }^{3}$ The optimal value of $n$, therefore, would be a function of $\mu$, and we would be able to observe how this optimal value of $n$ varies with $\mu$, given reasonable values for the parameters of the utility function.

The simulation methodology is as follows: Given a vector of initial conditions, the optimal values of $n$ have been estimated for different values of $\mu$. These are the "baseline" values of $n$. Thereafter, given that women with higher opportunity cost of time may be affected differently by uncertainty than those with low opportunity cost, $\mu$ and $w_{P}$ are changed simultaneously, and the optimal value of $n$ is generated for each combination of $n$ and $w_{P}$. This process generates vectors of $n$, one for each value of $w_{P}$, that can then be compared with the aforementioned "baseline" values.

INSERT Table 1 about here.

In Table 1, the shaded column highlights the "baseline" values of $n$. It can be seen that both $\mu$ and the wage rate have non-linear impacts on the optimal value of $n$. In particular, for low values of the wage rate, as the probability of being employed declines (reflecting an increase in job-related uncertainty), there is initially a decline in the optimal value of $n$. But beyond some threshold, this optimal value rises again, and then declines once more as $\mu$ continues to decrease in magnitude. On the other hand, when the wage rate is high, the optimal value of $n$ increases monotonically with increases in the value of $\mu$.

The derived patterns are fairly robust across feasible parameter vectors for which numerical solutions for the optimal value of $n$ could be obtained. However, the purpose of the simulation exercise is not to make predictions about the relationship between uncertainty and the optimal number of children, but rather to generate testable hypotheses. As such, the simulation

\footnotetext{
${ }^{3}$ Note that this algebraic formulation provides considerable flexibility. For example, it can represent uncertainty about her ability to work $t_{w}$ hours of labour per time period, given demand and supply side constraints such as the state of the economy and childcare availability. Alternatively, it could represent uncertainty regarding the wage rate, e.g., expecting to receive wage rate $w_{P}$ with probability $\mu$.
} 
results suggest that while, in general, uncertainty has a negative impact on childbearing decisions, the relationship between uncertainty and childbearing decision may be nonmonotonic, and may significantly depend on the opportunity cost of time of the parent.

\section{Specification and Data}

The model explored in the previous section suggests that the econometric specification required to explore the relationship between uncertainty and childbearing decision is given by

$$
n=\beta_{0}+\beta_{1} \mu^{\prime}+\beta_{2} \mu^{\prime 2}+\beta_{3} \mu^{\prime} * w_{P}+\Gamma^{\prime} \mathrm{C}+\varepsilon
$$

where $\mu^{\prime}$ is the inverse of $\mu,{ }^{4} C$ is a vector of control variables and $\varepsilon$ is the error term. However, equation (6) is not easy to estimate. Specifically, unless we were to choose a sample of women all of whom have become infertile on account of age, we would have no way of knowing the optimum value of $n$ for any of the women. Indeed, even if we were to focus on such a sample of women, the observed number of children for a woman would unlikely be her desired or optimum number of children. Hence, the dependent variable of equation (6) is unobservable. ${ }^{5}$ To overcome this problem, we modify the econometric specification to examine the determinants of observed births across a cross-section of women during a given time period. In other words, the dependent variable in the modified equation is no longer the optimum value of $n$, but rather a zero-one binary variable $(b)$ that captures the event of birth during a period of time. Note that this modification implicitly captures the logic implicit in equation (6) and the model described in the previous section; if a parent already has what she considers to be the optimal number of children, she would not give birth during a given period of time. If, on the other hand, she has fewer than the optimal number of children at the beginning of that time period, she may give birth provided she perceives the circumstances to be favourable. This specification has the additional advantage that it puts the emphasis on relatively short-term observations of uncertainty that as mentioned above were changing substantially from year to year. The modified econometric specification for a given time period $t$ is as follows:

$$
\mathrm{b}=\beta_{0}+\beta_{1} \mu^{\prime}+\beta_{2} \mu^{\prime 2}+\beta_{3} \mu^{\prime} * w_{P}+\Gamma^{\prime} \mathrm{C}+\varepsilon
$$

\footnotetext{
${ }^{4}$ Note that an increase in $\mu$ implies an increase in the level of income-related certainty, and hence an increase in $\mu$ ' implies an increase in uncertainty. Since we are emphasising the relationship between uncertainty and the fertility decisions, this transformation would prove to be useful later in the analysis.

${ }^{5}$ Indeed, given this measurement problem, it would have been unwise for us to use the otherwise innovative "hurdle count" method used by Kalwij (2000) to model the impact of female employment on the number of children in a household. Two additional assumptions of that method are unattractive in this context. First, it assumes that the mother has a firm expectation of the number of children. This seems implausible given the multiple sources of uncertainty operating in the transition economy setting under study here. Second, empirical application of the method was facilitated by the assumption that employment status of the woman would remain constant from soon after the birth of the first child. Again, in view of high unemployment rates and rapidly changing expectations about employment, this would be a very unpalatable assumption in this context.
} 
The control variables are as follows: age and square of age of the woman, her marital status, the number of children born to her prior to $t$, the average number of hours she spends per day for work or training, availability of parents or in-laws to provide childcare, a proxy for opportunity cost of her time, her educational attainment, employment status of her spouse, wealth status of the household, and the health status of the couple. The simulations of the model presented above suggest that we can expect $\beta_{1}$ to be negative, with the possibilities that $\beta_{2}$ and $\beta_{3}$ may be non-zero, i.e., the relationship between uncertainty and childbearing decision may be non-monotonic, and the nature of the relationship may significantly depend on the opportunity cost of time of the parent.

As mentioned above, these hypotheses are tested using the GSOEP data. This is a longitudinal survey of private households and persons in the Federal Republic of Germany, the first round of which was undertaken in 1984 (Haisken-Denew and Frick, 2000). In that and all subsequent years, the respondents were asked a core set of questions concerning demographic features of the household, income and social security benefits of the household members, their education, health and labour market performance, and expectations about the future. Prior to 1990 the survey was limited to West German households (numbering 5921 in 1984) but since then households in the former German Democratic Republic have also been included, raising the number of households included to about 6,800 and the number of individuals to about 13,000.

The GSOEP data provides a wealth of information on income and wealth of households, and on the individuals who reside in the surveyed households. Specifically, it provides information about the education levels of these individuals, the extent of their labour market participation, age, gender, and the number of children. Some of the rounds of the survey also provide detailed information about extended families of individuals, namely, parents, siblings, former spouses etc. Most importantly, the questionnaires for the different rounds of the survey included questions about the opinions of the respondents about the socio-economic atmosphere around them, and their expectations about the future. It is the responses to these questions that are used to create the uncertainty scores used in the regression analysis [see Table 2]. ${ }^{6}$

INSERT Table 2 about here.

As is evident from the table, we have been able to create scores for several different forms of uncertainty that an East German woman might have faced after the unification of Germany: three measures of general uncertainty about the aftermath of unification (UNCRT1P, UNCRT2P, UNCRT3P), uncertainty about the financial future of the household (UNCRT4P), employment

\footnotetext{
${ }^{6}$ Since childbirth normally occurs 9 months after conception, i.e., about a year after the "decision" to have a child, for any given year in which births are analysed, the uncertainty scores used are those of the previous year. For example, in analysing births in 1992, uncertainty scores from 1991 have been used.
} 
related uncertainty (UNCRT5P), and uncertainty about suitable childcare availability (UNCRT6P). Hence, equation (6a) has to be reformulated to explicitly take into consideration all these forms of uncertainty, and the resultant econometric specification is given by

$$
\mathrm{b}=\beta_{0}+\Sigma_{\mathrm{i}} \beta_{1 \mathrm{i}} \mu_{\mathrm{i}}{ }^{\prime}+\Sigma_{\mathrm{i}} \beta_{2 \mathrm{i}} \mu_{\mathrm{i}}{ }^{2}+\Sigma_{\mathrm{i}} \beta_{3 \mathrm{i}} \mu_{\mathrm{i}}{ }^{\prime} * w_{P}+\Gamma^{\prime} \mathrm{C}+\varepsilon
$$

where index $i$ refers to the $i$-th form of uncertainty $(i=1,2, \ldots, 6)$.

Available macroeconomic information suggests that the East German fertility rate declined sharply after the unification, reached its nadir around 1994, and has recovered slightly since then. In other words, 1994 is a possible "saddle point" representing a structural break. We, therefore, have analysed the relationship between fertility and uncertainty both before and after 1994. Specifically, we use the 1992 and 1996 rounds of the survey to explore the relationship embodied by equation (6b). There are two reasons as to why we chose to use this comparative cross-sectional approach rather than using a panel data/fixed-effects model to estimate equation (6b). First, a major weakness of the GSOEP is that some of the key questions are not comparable across surveys. For example, of the six forms of uncertainty described in Table 2, the first two were included in some of the questionnaires and excluded from some others. Similarly, while at least one of the post-1990 rounds of the survey gathered detailed information on the extended family/social network of the respondents, the relevant questions were excluded from many of the other rounds of the survey. ${ }^{7}$ Second, after accounting for missing data, the incidence of childbirth in the East German sample was less than 1 percent in the 1993-95 period, implying that there were too few women who gave birth during these years to obtain meaningful results on the determinants of fertility.

In Tables 3 and 4, we present comparative descriptive statistics for the women who did and did not experience childbirth during 1992 and 1996, respectively.

INSERT Table 3 about here.

INSERT Table 4 about here.

It is evident from Table 3 that the women who experienced childbirth during 1992 $(\mathrm{CBIRTH}=1)$ differed from those who did not $(\mathrm{CBIRTH}=0)$ in that they were clearly worse

\footnotetext{
${ }^{7}$ For example, the 1996 questionnaire included detailed information about both the perceived relationship and physical distance between the respondent and the members of her extended family/social network. This allowed us to create a dummy variable PCARE, for example, with a value of unity if at least one parent of a respondent woman (a) was alive in 1996, (b) was perceived to have good relationship with the woman, and (c) lived within a reasonable distance of her home. For 1996, dummy variables SECARE and SPCARE were defined in a similar way. Yet, not all such information was available for the 1992 respondents. For that year, the PCARE variable had to be constructed only on the basis of whether or not at least one parent of the woman or of her partner was alive. As a result, the PCARE variables for the two years are not comparable and those for SPCARE and SECARE not available at all, rendering infeasible the use of panel data techniques.
} 
off in terms of both income and wealth. The net household income of the women in the sample who gave birth during that year was about 38,450 marks, well below that of those who did not give birth (47,441 marks). Further, while 30 percent of the not birth-giving women lived in homes owned by their families, only 16 percent of the birth-giving women did so. Moreover, the homes of the latter were larger (79 square meters) compared to those of the former (66 square meters).

This inequity also spilled over into the labour market; 87 percent of the non-birth giving women were employed in 1992 compared to 75 percent for the birth-givers. ${ }^{8}$ The non-birth givers also enjoyed more prestigious jobs, as indicated by their average score on the TREIM scale. Prima facie, there is some evidence, therefore, that lower opportunity cost of time and the resultant substitution effect may have been a factor determining fertility in 1992. However, as mentioned in footnote 8 , the causal structure of the relationship between employment and childbirth is not clear, and one would have to control for other factors that might influence both employment and fertility. For example, women who did not give birth in 1992 reported as having, on average, 1.75 children prior to that, while those who did reported 1.16 children prior to that year. Assuming that a child is a normal good, prior to the incidence of childbirth in 1992 the marginal utility of a child was decidedly higher for the latter than for the former. Further, women who did not give birth in 1992 were, on average, older than those who did, indicating that age, too, may have played a role in fertility decisions.

The figures reported in Table 4 suggest that the situation was not much different in 1996. The women who gave birth in 1996 belonged to poorer families, were younger, less likely to be employed, and, on average, had less prestigious jobs. They also had fewer prior children (0.88) than the women who did not give birth (1.62) and were more likely to have partners without any major health problems, as indicated by hospital visits during the year (NOHSVT). ${ }^{9}$

Interestingly, however, the uncertainty scores were not significantly different for the birth-giving and non-birth-giving women in either 1992 or $1996 .{ }^{10}$ Hence, there is no prima facie evidence for a negative relationship between fertility and uncertainty. Yet, only in the next section where we control for other relevant factors can we get a more accurate picture of the relationship, obtaining thereby the conditional relation between uncertainty and childbirth.

In particular, our empirical analysis involves use of logit models to infer the relationship between the different forms of uncertainty and fertility decisions, after controlling for the characteristics of the women, their partners, and the households to which they belonged. The

\footnotetext{
${ }^{8}$ It should be noted that the causal structure of this relationship is not obvious. A woman may have decided to have a child because she was unemployed. But, it is also possible that she was unemployed because she gave birth during the year.

${ }^{9}$ The information about hospital visits was not available for people in the 1992 sample and thus no such scores for NOHSVT could be reported in Table 3.

${ }^{10}$ Note that, owing to differences between the questionnaires across years, it was not possible to construct scores for UNCRT1 and UNCRT2 for 1992 (i.e., as measured in 1991).
} 
sample for 1992 comprised of 500 observations, with just over 2 percent incidence of childbirth during the year. The sample for 1996 included 1093 observations, with about 6 percent incidence of childbirth during the year. The methodology used for the empirical analysis is described in further detail in the next section.

\section{Regression Results}

The regression analysis proceeds in three stages. For simplicity and to reduce an important source of multicollinearity, in the first stage we assume that the relationship between the zero-one incidence of childbirth and the various forms of uncertainty is linear, i.e., $\beta_{2 \mathrm{i}}$ and $\beta_{3 \mathrm{i}}$ are assumed to be zero. The right hand side variables include the six uncertainty scores, and the following controls: age of the woman in years (AGE), square of age (AGESQ), marital status (MARRIED), number of children prior to the year in question (KIDTIL92/KIDTIL96), average number of work hours of the woman per weekday (WHOUR), ${ }^{11}$ availability of parents (PCARE), former partners/spouses (SECARE) and partner's parents (SPCARE) to look after the children, number of years of education (NOYEDU), the prestige level of the woman's job (TREIM), ${ }^{12}$ employment status of the partner (SESTAT), size of the household's residence (SIZOHH), availability of liquid assets like bank savings (LIQAST), and number of hospital visits by the woman (NOHVST) and her partner (SNOHVST). ${ }^{13}$ The prestige level of her job is used as a proxy for the opportunity cost of her time, SIZOHH and LIQAST are proxies for household wealth, and NOHVST and SNOHVST are proxies for the health status of the household. In essence, a linearized version of equation ( $6 \mathrm{~b})$ is estimated.

In the second stage, the linearity assumption in (6b) is relaxed. Two different forms of non-linearity - quadratic terms for each form of uncertainty and interactions between each such form and the opportunity cost of time - are introduced in the specification. Hence, the full nonlinear version of equation $(6 b)$ is estimated.

Since as mentioned above, in the theoretical model a representative parent makes three decisions simultaneously, namely, childbirth, labour supply, and savings, in the third stage we

\footnotetext{
${ }^{11}$ WHOUR includes both hours of work and hours spent in training required to keep a job or to obtain a new one.

${ }^{12}$ It is reasonable to assume that the opportunity cost of a person's time, as measured by both monetary remunerations for labour and the non-monetary satisfaction associated with it, would be a monotonically increasing function of the prestige associated with it. For example, a civil servant's job is both more prestigious than a clerk's job, and both the monetary and non-monetary opportunity cost of time is higher for the former. There may, of course, be aberrations, but if such aberrations are random, it would still be reasonable to use the prestige associated with a job as a proxy for the opportunity cost of time of some involved in it. The GSOEP provides two highly correlated measure of the prestige associated with the jobs of the respondents; TREIM is one of the two measures.

${ }^{13}$ Since net income of the households is highly correlated with WHOUR, NOYEDU, TREIM, and SESTAT, hence either current income or the latter four measures of permanent income had to be excluded from the specification. On the belief that fertility decisions are more closely linked to permanent income than to current income, we chose to omit net household income from the specification.
} 
treat endogeneity. Given the extent of forced savings through taxes, the wide and generous coverage of the social security program for older people in Germany and the dearth of savings apparent in the data, however, we conclude that endogeneity in savings can be neglected. This still leaves labour supply (WHOUR) as a potentially endogenous variable and its endogeneity is confirmed by a Hausman test. Hence, it is instrumented for use in equation (6b).

The IV equations for WHOUR for both 1992 and 1996 are reported in Table 5. Labour supply is treated alternatively as an ordinary continuous variable estimated by OLS and as a leftcensored variable that is observed only when some latent variable crosses some pre-determined and unobserved threshold and is estimated by a Tobit regression. Since the GSOEP does not provide good instruments for estimating WHOUR (that would not have any influence on childbirth), we used the Lewbel (1997) method of higher moments of the same variable as the instruments.

INSERT Table 5 about here.

Table 6 reports the coefficient estimates for the linear version of equation (6b), obtained using both the 1992 and 1996 data and the fitted values of WHOUR generated by the OLS and Tobit instrumentation exercises reported earlier. ${ }^{14}$ The pseudo R-square values of 0.27 for 1992 and 0.23 for 1996, are relatively satisfactory for cross-section data of this sort and the values of Chi-square are highly significant. The results show that both in 1992 and 1996 age is nonlinearly related to the probability of childbirth, rising up to a certain age, levelling off and then declining. Similarly, both in 1992 and 1996 the probability of childbirth declines with both the number of children born earlier (KIDTIL92 and KIDTIL96) and the opportunity cost of time, as measured by the TREIM job prestige index. Perhaps on account of the larger sample and consequently greater variation across individuals in 1996, the coefficient of the former is significant only for the 1996 sample. Similarly, the effect of household wealth as measured by SIZOHH is positive and significant only for 1996. None of the other control variables has any significance in explaining the probability of childbirth. Overall, a child seems to be a normal good, and the signs of the significant control coefficients are as expected. However, the most important results are those with respect to uncertainty. Financial uncertainty (UNCRT4P) had a significant and negative effect on childbirth in 1992, while employment related uncertainty (UNCRT5P) had a significant and negative effect on childbirth in 1996. The results are robust to the different types of estimation procedures used in the instrumentation of WHOUR.

\footnotetext{
${ }^{14}$ The difference in specification for the 1992 and 1996 samples reflects both the aforementioned greater availability of information on the women, their partners, and their households from the 1996 survey and multicollinearity resulting from insufficient variation in the 1992 values of some of the variables. For example, 100 percent of the partners of the women in the 1992 sample reported at least one living parent. Hence, SPCARE takes the value 1 for all observations (see footnote 4). Similar problems surfaced with respect to LIQAST and SESTAT.
} 
INSERT Table 6 about here.

Next, the two different types of non-linearity with respect to uncertainty are introduced in the specification, resulting in the full non-linear and interactive version of equation (6b). Since the other results are left unaffected, only the results for these terms are reported, those for 1992 are reported in Table 7 and those for 1996 in Table 8. In each case, the results are given for the alternative OLS and Tobit procedures for obtaining the fitted values of WHOUR and for two different specifications. Specification 1 includes the uncertainty scores in linear form as well as their interaction with the opportunity cost of time (TREIM). Specification 2 includes the uncertainty scores in both linear and quadratic forms but not their interactions with TREIM.

The introduction of the non-linearities changes the results in interesting ways. In particular, for 1992 (Table 7), when interactions with TREIM are introduced as in Specification 1, the financial uncertainty variable (UNCRT4P) remains statistically significant but only when interacted with TREIM. This indicates that the negative effect of financial uncertainty has its negative effect on childbirth primarily only for women with relatively high opportunity costs of time. At the same time, if the non-linearity is confined to the square terms (without the interactions with TREIM) as in Specification 2, it is only uncertainty about childcare availability (UNCRT6P) that has a negative and significant effect on the probability of childbirth.

For 1996, the introduction of the non-linearity (Table 8) shows the negative influence of uncertainty about job security (UNCRT5P) to be robust both to the alternative specifications and to the method for generating the fitted values of WHOUR. The version with the interactions with TREIM also reveals a small but significant negative influence of the TREIM-UNCRT1P interaction term, indicating that general uncertainty about the future (UNCRT1P) has a negative effect on childbirth probabilities when the opportunity costs of time are high. The version without the interaction terms but with the squared uncertainty measures shows the effect of one's own financial uncertainty (UNCRT4P) to be negative only at high levels of UNCRT4P.

In general, the introduction of the non-linearities so as to be more directly consistent with the theoretical model has the effect of increasing the explanatory power of the empirical model and at the same time provides additional evidence concerning the negative effects of at least four different types of uncertainty on the probability of childbirth.

\section{Conclusions}

We developed a three period overlapping generation micro model of fertility that shows that financial and employment uncertainty would be likely to have negative effects on fertility. The micro-level data from a sample of East German households provides direct and time-varying 
observations on several forms of uncertainty. The results provide at least tentative empirical support for this result of the model as well as for some of the other more standard ones. These results would seem to support the idea that increases in uncertainty subsequent to the transition of East Germany into a market oriented Federal Republic of Germany could have contributed significantly to the dramatic decline in fertility in that formerly socialist country that was observed in the early to mid 1990s. The fact that these uncertainties seem to have declined ${ }^{15}$ in recent years, especially after 1994, may also explain why the decline in fertility seems to have stalled and even reversed in the last few years.

By no means do we wish to deny the relevance of other determinants of the fertility decline such as the fall in real income, attitudinal and other socioeconomic changes. Indeed, several of these explanations are likely to be interdependent. Some of these interdependencies and distinctive influences could be better sorted out if the panel data potential of this rich data set could be realized. For reasons given above, this is not yet possible. But, eventually it could be due to the increasing sample size and more complete questionnaires used in the surveys of recent years. In that way, eventually more could be done to test for the relative importance of different factors to the differences in fertility not just across households but also over time. This might also suggest the need to construct better measures of income and wealth as well as of other socio-economic variables.

Nevertheless, even as they are the results provide encouragement for the idea that risk considerations should be given somewhat greater emphasis than they generally do in such explanations of fertility fluctuations over time. Future research along these lines could benefit from better measures of the different kinds of uncertainty. Other issues that could be explored would be the relative importance of uncertainty measures of the husband and wife and the determinants of these uncertainty measures. Our data show that these uncertainty measures did vary from year to year, even for the same individuals, and that childbearing decisions of East German women were affected by different forms of uncertainty in different years of the survey.

Another relevant issue that needs further investigation is the extent to which such fertility swings are desirable. In other words, are there negative external effects of fertility cycles of the type that the transition economies have experienced? A related question that should perhaps be addressed is that, if such fertility swings are indeed undesirable, how, and to what extent should government intervention in the form of subsidies for retraining and childcare, as well as those involving pensions and other forms of social security be encouraged? Also, to what extent would these policies affect fertility rates? This, indeed, remains the focus of our future research.

\footnotetext{
${ }^{15}$ By comparing the means for UNCRT4P and UNCRT6P for the two years from Tables 3 and 4, it can be seen that in the full sample there was a reduction of some 15 percent in both these measures of uncertainty between 1991 and 1995 .
} 


\section{References}

Adler, Marina A. (1997) "Social Change and Declines in Marriage and Fertility in Eastern Germany," Journal of Marriage and the Family, 59 (February), 37-49.

Becker, Gary S. (1976) "An Economic Analysis of Fertility," in The Economic Approach to Human Behavior, Chicago: University of Chicago Press, 171-194.

Cain, Mead (1980) "Risk, Fertility and Family Planning in a Bangladesh Village," Studies in Family Planning, 11, 219-223.

Cain, Mead (1981) "Risk and Insurance: Perspectives on Fertility and Agrarian Change in India and Bangladesh," Population and Development Review, 7 (3), 435-474.

Cain, Mead (1983) "Fertility as an Adjustment to Risk," Population and Development Review, 9 (4), 688-702.

Easterlin, Richard A. Robert A. Pollak and Michael L. Wachter (1980) "Toward a More General Economic Model of Fertility Determination: Endogenous Preferences and Natural Fertility" in R.A. Easterlin, ed., Population and Economic Change in Developing Countries. Chicago: University of Chicago Press.

Haisken-DeNew, J. P. and J. R. Frick (2000) Desktop Companion to the German SocioEconomic Panel, version 3, Berlin: DIW.

Hunt, Jennifer (1997) “The Transition in East Germany: When Is a Ten Point Fall in the Gender Gap Bad News?” Cambridge: NBER Working Paper 6167.

Kalwij, Adriaan S. (2000) "The Effects of Female Employment Status on the Presence and Number of Children", Journal of Population Economics, 13, 221-239.

Kreyenfeld, Michaela (2000a) "Employment Careers and the Timing of First Births in East Germany," Rostock: Max Planck Institute for Demographic Research Working Paper 2000-004.

Kreyenfeld, Michaela (2000b) "Educational Attainment and First Birth in East Germany," Rostock: Max Planck Institute for Demographic Research Working Paper 2000-011.

Leibenstein, Harvey (1957) Economic Backwardness and Economic Growth. New York: John Wiley.

Leibenstein, Harvey (1978) General X-Efficiency Theory and Economic Development. London: Oxford University Press.

Lewbel, A. (1997) "Constructing Instruments for Regressions with Measurement Error When No Additional Data are Available with an Application to Patents and R\&D," Econometrica, 65, 1201-1213. 
Micevska, Maja B. (2001) "Economic Disruption, Malthusian Fertility, and Economic Growth," Mimeo, Claremont: Claremont Graduate University.

Micevska, Maja B. and Paul J. Zak (2002) "What Accounts for the Emergence of Malthusian Fertility in Transition Economies?" Mimeo, Claremont: Claremont Graduate University.

Ranjan, Priya (1999) "Fertility Behavior under Income Uncertainty," European Journal of Population, 15, 25-43.

Stortzbach, Bernd (1995) "Germany Unification in Attitudes?" in Hein Moors and Rossella Palomba, eds. Population, Family and Welfare: A Comparative Survey of European Attitudes, Vol. 1, Oxford: Clarendon Press, 122-138.

Witte, James C. and Gert G. Wagner (1995) "Declining Fertility in East Germany after Unification: A Demographic Response to Socioeconomic Change," Population and Development Review 21 (June), 387-397.

Zapf, Wofgang and Steffan Mau (1993) “A Demographic Revolution in Eastern Germany," (in German) Informationsdienst Soziale Indikatoren 10 (July), 1-5 . 
Table 1

Optimal Values of the Number of Children (n) for Different $\mu$ and $w^{p}$

\begin{tabular}{|l|c|c|c|r|r|r|}
\hline \multirow{2}{*}{$\boldsymbol{\mu}$} & \multicolumn{6}{|c|}{$\mathbf{w}_{\mathbf{p}}$} \\
\cline { 2 - 7 } & $\mathbf{0 . 0 2 5}$ & $\mathbf{0 . 0 5 0}$ & $\mathbf{0 . 0 7 5}$ & $\mathbf{0 . 1 0 0}$ & $\mathbf{0 . 1 2 5}$ & $\mathbf{0 . 1 5 0}$ \\
\hline $\mathbf{0 . 5 0}$ & 1.2886 & 1.3300 & 1.4027 & 0.4787 & 0.6834 & 2.5390 \\
\hline $\mathbf{0 . 5 5}$ & 1.2942 & 1.3494 & 0.3848 & 0.6162 & 2.3983 & 3.6630 \\
\hline $\mathbf{0 . 6 0}$ & 1.3002 & 1.3732 & 0.4727 & 0.7451 & 3.2330 & 5.3149 \\
\hline $\mathbf{0 . 6 5}$ & 1.3067 & 1.4027 & 0.5815 & 2.5390 & 4.4185 & 7.5711 \\
\hline $\mathbf{0 . 7 0}$ & 1.2886 & 0.3567 & 0.6834 & 3.2330 & 5.9956 & 10.5215 \\
\hline $\mathbf{0 . 7 5}$ & 1.3215 & 0.4147 & 2.1541 & 4.1515 & 8.0121 & 14.2639 \\
\hline $\mathbf{0 . 8 0}$ & 1.3300 & 0.4787 & 2.5390 & 5.3149 & 10.5215 & 18.9021 \\
\hline $\mathbf{0 . 8 5}$ & 1.3392 & 0.5468 & 3.0392 & 6.7466 & 13.5808 & 24.5440 \\
\hline $\mathbf{0 . 9 0}$ & 1.3494 & 0.6162 & 3.6630 & 8.4728 & 17.2499 & 31.3012 \\
\hline $\mathbf{0 . 9 5}$ & 1.3607 & 0.6834 & 4.4185 & 10.5215 & 21.5907 & 39.2886 \\
\hline $\mathbf{1 . 0 0}$ & 1.3732 & 0.7451 & 5.3149 & 12.9221 & 26.6669 & 48.6259 \\
\hline
\end{tabular}

Table 2

Uncertainty Scores

\begin{tabular}{|c|c|c|c|c|}
\hline Variable & Question & Response Categories & Min. & Max. \\
\hline UNCRT1P & $\begin{array}{l}\text { When I think about the } \\
\text { future, I am filled with } \\
\text { confidence. }\end{array}$ & $\begin{array}{l}\text { a. applies completely } \\
\text { b. applies more or less } \\
\text { c. does not really apply } \\
\text { d. does not apply }\end{array}$ & 1 & 4 \\
\hline UNCRT2P & $\begin{array}{l}\text { Everything has become so } \\
\text { complicated that I am } \\
\text { barely able to cope with } \\
\text { it all. }\end{array}$ & $\begin{array}{l}\text { a. does not apply } \\
\text { b. does not really apply } \\
\text { c. applies more or less } \\
\text { d. applies completely }\end{array}$ & 1 & 4 \\
\hline UNCRT3P & $\begin{array}{l}\text { Does general economic } \\
\text { development worry you? }\end{array}$ & $\begin{array}{l}\text { a. not worried } \\
\text { b. slightly worried } \\
\text { c. very worried }\end{array}$ & 1 & 3 \\
\hline UNCRT4P & $\begin{array}{l}\text { Does your own financial } \\
\text { situation worry you? }\end{array}$ & $\begin{array}{l}\text { a. not worried } \\
\text { b. slightly worried } \\
\text { c. very worried }\end{array}$ & 1 & 3 \\
\hline UNCRT5P & $\begin{array}{l}\text { If employed, does the } \\
\text { security of your job worry } \\
\text { you? } \\
\text { If not gainfully employed, } \\
\text { and if you were looking } \\
\text { for a job now, how } \\
\text { easy would it be to find a } \\
\text { job? }\end{array}$ & $\begin{array}{l}\text { a. not worried } \\
\text { b. slightly worried } \\
\text { c. very worried } \\
\text { d. easy } \\
\text { e. difficult } \\
\text { f. practically impossible }\end{array}$ & 1 & 6 \\
\hline UNCRT6P & $\begin{array}{l}\text { If you have small children } \\
\text { in your family, does it } \\
\text { worry you as to who } \\
\text { will take care of them? }\end{array}$ & $\begin{array}{l}\text { a. no children } \\
\text { b. not worried } \\
\text { c. slightly worried } \\
\text { d. very worried }\end{array}$ & 0 & 3 \\
\hline
\end{tabular}


Table 3

Summary Statistics for 1992: Comparison of Households with Childbirth and without Childbirth During the Year

\begin{tabular}{|c|c|c|c|c|}
\hline \multirow[b]{2}{*}{ Variable } & \multicolumn{2}{|c|}{ CBIRTH $=0$} & \multicolumn{2}{|c|}{ CBIRTH = 1} \\
\hline & Means & Std. Dev. & Means & Std. Dev. \\
\hline \multicolumn{5}{|l|}{ Household Characteristics } \\
\hline Net income for the household (NETINC) & 47441.95 & 16393.47 & 38450.90 & 13196.30 \\
\hline Percentage owning home (HOWNER) & 30 & 45 & 16 & 38 \\
\hline Size of the home in square meters (SIZOHH) & 79.08 & 30.09 & 66.83 & 24.75 \\
\hline Percentage owning liquid assets (LIQAST) & 95 & 21 & 100 & 0 \\
\hline \multicolumn{5}{|l|}{ Women's Characteristics } \\
\hline Age (AGE) & 36.60 & 6.98 & 30.91 & 5.38 \\
\hline Number of years of education (NOYEDU) & 12.96 & 2.36 & 12.83 & 1.21 \\
\hline Percentage married (MARRIED) & & & 91 & 28 \\
\hline $\begin{array}{l}\text { Number of children born prior to } 1992 \\
\text { (KIDTIL92) }\end{array}$ & 1.75 & 0.83 & 1.16 & 1.19 \\
\hline $\begin{array}{l}\text { Percentage of women for whom at least one } \\
\text { parent is alive and resident near the household } \\
\text { (PCARE) }\end{array}$ & 34 & 47 & 50 & 52 \\
\hline $\begin{array}{l}\text { Percentage of women for whom spouse or ex- } \\
\text { spouse is alive (SECARE) }\end{array}$ & n.a. & n.a. & n.a. & n.a. \\
\hline Percentage employed (ESTAT) & 87 & 33 & 75 & 45 \\
\hline $\begin{array}{l}\text { Average number of hours spent for work and } \\
\text { training per day (WHOUR) }\end{array}$ & 7.26 & 3.81 & 3.91 & 4.88 \\
\hline Job score on TREIM prestige scale (TREIM) & 32.80 & 21.08 & 16.27 & 20.72 \\
\hline $\begin{array}{l}\text { Percentage enrolled in school/college or } \\
\text { training during the year (EDUC) }\end{array}$ & 11 & 32 & 8 & 28 \\
\hline $\begin{array}{l}\text { Number of hospital visits during the year } \\
\text { (NOHVST) }\end{array}$ & n.a. & n.a. & n.a. & n.a. \\
\hline \multicolumn{5}{|l|}{ Partner's Characteristics } \\
\hline Number of years of education (SNOYEDU) & 12.98 & 2.56 & 12.87 & 3.24 \\
\hline Percentage employed (SESTAT) & 97 & 14 & 100 & 0 \\
\hline $\begin{array}{l}\text { Percentage of men for whom at least one parent } \\
\text { is alive (SPCARE) }\end{array}$ & 100 & 0 & 100 & 0 \\
\hline $\begin{array}{l}\text { Number of hospital visits during the year } \\
\text { (SNOHVST) }\end{array}$ & n.a. & n.a. & n.a. & n.a. \\
\hline \multicolumn{5}{|l|}{ Uncertainty Scores } \\
\hline Confidence about future (UNCRT1P) & n.a. & n.a. & n.a. & n.a. \\
\hline Ability to cope with changes (UNCRT2P) & n.a. & n.a. & n.a. & n.a. \\
\hline General economic development (UNCRT3P) & 2.50 & 0.55 & 2.33 & 0.65 \\
\hline Own financial situation (UNCRT4P) & 2.35 & 0.59 & 2.08 & 0.66 \\
\hline Job security (UNCRT5P) & 2.83 & 1.28 & 3.00 & 1.41 \\
\hline Childcare (UNCRT6P) & 1.13 & 1.16 & 1.96 & 0.93 \\
\hline \multicolumn{5}{|l|}{ Number of Observations } \\
\hline & & 526 & & 12 \\
\hline
\end{tabular}


Table 4

Summary Statistics for 1996: Comparison of Households with Childbirth and without Childbirth During the Year

\begin{tabular}{|c|c|c|c|c|}
\hline \multirow[b]{2}{*}{ Variable } & \multicolumn{2}{|c|}{ CBIRTH = 0 } & \multicolumn{2}{|c|}{ CBIRTH = 1} \\
\hline & Means & Std. Dev. & Means & Std. Dev. \\
\hline \multicolumn{5}{|l|}{ Household Characteristics } \\
\hline Net income for the household (NETINC) & 64506.36 & 29438.45 & 53102.93 & 20801.46 \\
\hline Percentage owning home (HOWNER) & 30 & 45 & 20 & 40 \\
\hline Size of the home in square meters (SIZOHH) & 98.84 & 38.31 & 93.20 & 41.97 \\
\hline Percentage owning liquid assets (LIQAST) & 87 & 32 & 82 & 38 \\
\hline \multicolumn{5}{|l|}{ Women's Characteristics } \\
\hline Age (AGE) & 36.17 & 7.22 & 28.81 & 4.52 \\
\hline Number of years of education (NOYEDU) & 12.25 & 2.88 & 11.22 & 1.88 \\
\hline Percentage married (MARRIED) & 88 & 31 & 82 & 38 \\
\hline $\begin{array}{l}\text { Number of children born prior to } 1996 \\
\text { (KIDTIL96) }\end{array}$ & 1.62 & 1.12 & 0.88 & 0.99 \\
\hline $\begin{array}{l}\text { Percentage of women for whom at least one } \\
\text { parent is alive and resident near the household } \\
\text { (PCARE) }\end{array}$ & 28 & 45 & 27 & 44 \\
\hline $\begin{array}{l}\text { Percentage of women for whom spouse or ex- } \\
\text { spouse is alive and resident in/near the } \\
\text { household (SECARE) }\end{array}$ & 1 & 13 & 2 & 16 \\
\hline Percentage employed (ESTAT) & 59 & 49 & 49 & 50 \\
\hline $\begin{array}{l}\text { Average number of hours spent for work and } \\
\text { training per day (WHOUR) }\end{array}$ & 5.06 & 4.24 & 3.28 & 4.45 \\
\hline Job score on TREIM prestige scale (TREIM) & 25.60 & 21.96 & 14.27 & 20.43 \\
\hline $\begin{array}{l}\text { Enrolment in school/college or training during } \\
\text { the year (EDUC) }\end{array}$ & 5 & 22 & 1 & 12 \\
\hline $\begin{array}{l}\text { Number of hospital visits during the year } \\
\text { (NOHVST) }\end{array}$ & 0.14 & 0.52 & 0.95 & 0.60 \\
\hline \multicolumn{5}{|l|}{ Partner's Characteristics } \\
\hline Number of years of education (SNOYEDU) & 12.95 & 3.24 & 11.89 & 2.35 \\
\hline Percentage employed (SESTAT) & 92 & 26 & 89 & 30 \\
\hline $\begin{array}{l}\text { Percentage of men for whom at least one parent } \\
\text { is alive and resident in/near the household } \\
\text { (SPCARE) }\end{array}$ & 13 & 34 & 10 & 30 \\
\hline $\begin{array}{lllll}\begin{array}{l}\text { Number of } \\
\text { (SNOHVST) }\end{array} & \text { hospital visits } & \text { during } & 1996 \\
\end{array}$ & 10 & 63 & 4 & 20 \\
\hline \multicolumn{5}{|l|}{ Uncertainty Scores } \\
\hline Confidence about future (UNCRT1P) & 2.15 & 0.69 & 1.97 & 0.64 \\
\hline Ability to cope with changes (UNCRT2P) & 1.60 & 0.78 & 1.65 & 0.76 \\
\hline General economic development (UNCRT3P) & 2.15 & 0.54 & 2.10 & 0.48 \\
\hline Own financial situation (UNCRT4P) & 1.97 & 0.65 & 2.05 & 0.51 \\
\hline Job security (UNCRT5P) & 2.85 & 1.77 & 2.86 & 1.86 \\
\hline Childcare (UNCRT6P) & 0.96 & 0.96 & 1.08 & 1.14 \\
\hline \multicolumn{5}{|l|}{ Number of Observations } \\
\hline & & 1024 & & 69 \\
\hline
\end{tabular}


Table 5

IV Equations for Labor Supply in 1992 and 1996

\begin{tabular}{|c|c|c|c|c|}
\hline & \multicolumn{2}{|c|}{1992} & \multicolumn{2}{|c|}{1996} \\
\hline & OLS & Tobit & OLS & Tobit \\
\hline Constant & $\begin{array}{l}0.1733 \\
(1.1982) \\
\end{array}$ & $\begin{array}{c}-0.6411 \\
(0.3949) \\
\end{array}$ & $\begin{array}{l}0.0870 \\
(0.6696)\end{array}$ & $\begin{array}{c}-0.9207 \\
(0.9853)\end{array}$ \\
\hline $\mathrm{AGE}$ & $\begin{array}{l}0.0967 \\
(0.0642)\end{array}$ & $\begin{array}{l}0.1166 \\
(0.0950)\end{array}$ & $\begin{array}{l}0.0994 * * \\
(0.0400)\end{array}$ & $\begin{array}{l}0.1381 * * \\
(0.0584)\end{array}$ \\
\hline AGESQ & $\begin{array}{c}-0.0014 * * * \\
(0.0008)\end{array}$ & $\begin{array}{c}-0.0017 * * * \\
(0.0010)\end{array}$ & $\begin{array}{c}-0.0011^{* *} \\
(0.0005)\end{array}$ & $\begin{array}{c}-0.0015^{* *} \\
(0.0007)\end{array}$ \\
\hline MARRIED & $\begin{array}{r}-0.0156 \\
(0.2306) \\
\end{array}$ & $\begin{array}{c}-0.0137 \\
(0.2339) \\
\end{array}$ & $\begin{array}{r}-0.2535^{*} \\
(0.0931) \\
\end{array}$ & $\begin{array}{c}-0.3215^{* *} \\
(0.1317) \\
\end{array}$ \\
\hline KIDTIL92/KIDTIL96 & $\begin{array}{l}0.0503 \\
(0.0535)\end{array}$ & $\begin{array}{l}0.0650 \\
(0.0627)\end{array}$ & $\begin{array}{r}-0.0881^{*} \\
(0.0292) \\
\end{array}$ & $\begin{array}{r}-0.1398^{*} \\
(0.0437)\end{array}$ \\
\hline PCARE & $\begin{array}{l}0.0778 \\
(0.0851)\end{array}$ & $\begin{array}{l}0.0801 \\
(0.1098)\end{array}$ & $\begin{array}{l}0.1145 \\
(0.0614)\end{array}$ & $\begin{array}{l}0.1531 \\
(0.0891)\end{array}$ \\
\hline SECARE & & & $\begin{array}{c}-0.1453 \\
(0.2053)\end{array}$ & $\begin{array}{r}-0.3048 \\
(0.3132)\end{array}$ \\
\hline SPCARE & & & $\begin{array}{l}0.0594 \\
(0.0814)\end{array}$ & $\begin{array}{l}0.1095 \\
(0.1181)\end{array}$ \\
\hline NOYEDU & $\begin{array}{r}-0.0858^{*} \\
(0.0219)\end{array}$ & $\begin{array}{r}-0.0977^{*} \\
(0.0238)\end{array}$ & $\begin{array}{r}-0.0849 * \\
(0.0106)\end{array}$ & $\begin{array}{r}-0.1296 * \\
(0.0160)\end{array}$ \\
\hline TREIM & $\begin{array}{r}-0.0386 * \\
(0.0035)\end{array}$ & $\begin{array}{l}0.0446 * \\
(0.0033)\end{array}$ & $\begin{array}{l}0.0490 * \\
(0.0018)\end{array}$ & $\begin{array}{l}0.0654^{*} \\
(0.0026)\end{array}$ \\
\hline SESTAT & $\begin{array}{l}0.1786 \\
(0.2536)\end{array}$ & $\begin{array}{l}0.2343 \\
(0.3549)\end{array}$ & $\begin{array}{c}-0.1402 \\
(0.1041)\end{array}$ & $\begin{array}{r}-0.1838 \\
(0.1511)\end{array}$ \\
\hline SIZOHH & $\begin{array}{l}0.0011 \\
(0.0014) \\
\end{array}$ & $\begin{array}{l}0.0013 \\
(0.0017) \\
\end{array}$ & $\begin{array}{c}-0.0007 \\
(0.0007) \\
\end{array}$ & $\begin{array}{c}-0.0007 \\
(0.0010) \\
\end{array}$ \\
\hline LIQAST & $\begin{array}{l}0.0787 \\
(0.2589) \\
\end{array}$ & $\begin{array}{l}0.1095 \\
(0.2408)\end{array}$ & $\begin{array}{l}0.0068 \\
(0.0862)\end{array}$ & $\begin{array}{l}0.0983 \\
(0.1310)\end{array}$ \\
\hline NOHVST & & & $\begin{array}{c}-0.0347 \\
(0.0494)\end{array}$ & $\begin{array}{r}-0.0594 \\
(0.0950)\end{array}$ \\
\hline SNOHVST & & & $\begin{array}{l}0.1207 * \\
(0.0451) \\
\end{array}$ & $\begin{array}{l}0.1596^{*} \\
(0.0629) \\
\end{array}$ \\
\hline Instrument & $\begin{array}{l}0.0742 * \\
(0.0020)\end{array}$ & $\begin{array}{l}0.0772 * \\
(0.0015)\end{array}$ & $\begin{array}{l}0.0730 \\
(0.0008)\end{array}$ & $\begin{array}{l}0.0751 \\
(0.0010)\end{array}$ \\
\hline$\sigma$ & & $\begin{array}{l}1.1445 \\
(0.0406) \\
\end{array}$ & & $\begin{array}{l}1.2257 \\
(0.0343) \\
\end{array}$ \\
\hline $\begin{array}{l}\text { F/Chi-sq statistic } \\
(\text { Prob > |statistic|) }\end{array}$ & $\begin{array}{l}411.21 \\
(0.00)\end{array}$ & $\begin{array}{l}1299.72 \\
(0.00)\end{array}$ & $\begin{array}{l}1547.36 \\
(0.00)\end{array}$ & $\begin{array}{l}2576.37 \\
(0.00)\end{array}$ \\
\hline (Pseudo) R-sq & 0.9378 & 0.4568 & 0.9557 & 0.4790 \\
\hline $\mathrm{N}$ & 538 & 538 & 1093 & 1093 \\
\hline
\end{tabular}

Notes: 1 . The values within parentheses are standard errors.

2. *, ** and $* * *$ indicate significance at the 1 percent, 5 percent and 10 percent levels respectively. 
Table 6

Determinants of Childbirth in 1992 and 1996 (IV)

\begin{tabular}{|c|c|c|c|c|}
\hline & \multicolumn{2}{|c|}{1992} & \multicolumn{2}{|c|}{1996} \\
\hline & OLS IV & Tobit IV & OLS IV & Tobit IV \\
\hline Constant & $\begin{array}{r}-8.8007 \\
(8.4132)\end{array}$ & $\begin{array}{r}-8.8526 \\
(8.4347)\end{array}$ & $\begin{array}{r}-4.7607 \\
(4.1492)\end{array}$ & $\begin{array}{r}-4.7979 \\
(4.1479)\end{array}$ \\
\hline $\mathrm{AGE}$ & $\begin{array}{l}0.8671 * * * \\
(0.5173)\end{array}$ & $\begin{array}{l}0.8683 * * * \\
(0.5179)\end{array}$ & $\begin{array}{l}0.4956 * * * \\
(0.2752)\end{array}$ & $\begin{array}{l}0.4980 * * * \\
(0.2754)\end{array}$ \\
\hline AGESQ & $\begin{array}{c}-0.0148^{* * *} \\
(0.0077)\end{array}$ & $\begin{array}{c}-0.0148 * * * \\
(0.0077)\end{array}$ & $\begin{array}{c}-0.0096 * * \\
(0.0043)\end{array}$ & $\begin{array}{c}-0.0096 * * \\
(0.0043)\end{array}$ \\
\hline MARRIED & $\begin{array}{l}0.2626 \\
(1.1873)\end{array}$ & $\begin{array}{l}0.2628 \\
(1.1872)\end{array}$ & $\begin{array}{r}-0.1025 \\
(0.4579)\end{array}$ & $\begin{array}{r}-0.1108 \\
(0.4591)\end{array}$ \\
\hline KIDTIL92/KIDTIL96 & $\begin{array}{r}-1.1838 \\
(0.8742)\end{array}$ & $\begin{array}{r}-1.1829 \\
(0.8747)\end{array}$ & $\begin{array}{r}-0.8287 * \\
(0.3022)\end{array}$ & $\begin{array}{r}-0.8334^{*} \\
(0.3032)\end{array}$ \\
\hline WHOUR (fitted) & $\begin{array}{r}-0.0724 \\
(0.1387)\end{array}$ & $\begin{array}{r}-0.0696 \\
(0.1333)\end{array}$ & $\begin{array}{c}-0.0360 \\
(0.0696)\end{array}$ & $\begin{array}{c}-0.0400 \\
(0.0680)\end{array}$ \\
\hline PCARE & $\begin{array}{l}0.1511 \\
(0.6167)\end{array}$ & $\begin{array}{l}0.1511 \\
(0.6166)\end{array}$ & $\begin{array}{r}-0.2411 \\
(0.2936)\end{array}$ & $\begin{array}{r}-0.2385 \\
(0.2938)\end{array}$ \\
\hline SECARE & & & $\begin{array}{l}0.8925 \\
(0.7471)\end{array}$ & $\begin{array}{l}0.8875 \\
(0.7469)\end{array}$ \\
\hline SPCARE & & & $\begin{array}{r}-0.5948 \\
(0.4346)\end{array}$ & $\begin{array}{c}-0.5905 \\
(0.4348)\end{array}$ \\
\hline NOYEDU & $\begin{array}{l}0.0927 \\
(0.0839)\end{array}$ & $\begin{array}{l}0.0921 \\
(0.0839)\end{array}$ & $\begin{array}{r}-0.1370^{*} \\
(0.0480)\end{array}$ & $\begin{array}{r}-0.1390^{*} \\
(0.0483)\end{array}$ \\
\hline TREIM & $\begin{array}{r}-0.0481^{*} \\
(0.0185)\end{array}$ & $\begin{array}{c}-0.0478 * * \\
(0.0189)\end{array}$ & $\begin{array}{c}-0.0280 * * \\
(0.0130)\end{array}$ & $\begin{array}{c}-0.0265 * * * \\
(0.0142)\end{array}$ \\
\hline SESTAT & & & $\begin{array}{c}-0.3359 \\
(0.5048) \\
\end{array}$ & $\begin{array}{r}-0.3405 \\
(0.5050) \\
\end{array}$ \\
\hline SIZOHH & $\begin{array}{c}-0.0165 \\
(0.0121) \\
\end{array}$ & $\begin{array}{c}-0.0165 \\
(0.0121) \\
\end{array}$ & $\begin{array}{l}0.0072 * * \\
(0.0033)\end{array}$ & $\begin{array}{l}0.0072 * * \\
(0.0033)\end{array}$ \\
\hline LIQAST & & & $\begin{array}{r}-0.2486 \\
(0.4082)\end{array}$ & $\begin{array}{r}-0.2478 \\
(0.4083)\end{array}$ \\
\hline UNCRT1P & & & $\begin{array}{r}-0.1722 \\
(0.2308)\end{array}$ & $\begin{array}{r}-0.1715 \\
(0.2328)\end{array}$ \\
\hline UNCRT2P & & & $\begin{array}{l}0.0735 \\
(0.1814)\end{array}$ & $\begin{array}{l}0.0733 \\
(0.1813)\end{array}$ \\
\hline UNCRT3P & $\begin{array}{r}-0.4396 \\
(0.5173)\end{array}$ & $\begin{array}{r}-0.4396 \\
(0.5173)\end{array}$ & $\begin{array}{c}-0.0673 \\
(0.2389)\end{array}$ & $\begin{array}{r}-0.0676 \\
(0.2388)\end{array}$ \\
\hline UNCRT4P & $\begin{array}{c}-0.9413 * * \\
(0.3840)\end{array}$ & $\begin{array}{c}-0.9413 * * \\
(0.3840)\end{array}$ & $\begin{array}{l}0.1843 \\
(0.2154)\end{array}$ & $\begin{array}{l}0.1851 \\
(0.2153)\end{array}$ \\
\hline UNCRT5P & $\begin{array}{r}-0.1788 \\
(0.3295)\end{array}$ & $\begin{array}{r}-0.1788 \\
(0.3295)\end{array}$ & $\begin{array}{c}-0.1662 * * * \\
(0.0935)\end{array}$ & $\begin{array}{c}-0.1663 * * * \\
(0.0934)\end{array}$ \\
\hline UNCRT6P & $\begin{array}{r}-0.1612 \\
(0.2386)\end{array}$ & $\begin{array}{r}-0.1612 \\
(0.2386)\end{array}$ & $\begin{array}{l}0.2285 \\
(0.1866)\end{array}$ & $\begin{array}{l}0.2270 \\
(0.1866)\end{array}$ \\
\hline $\begin{array}{l}\text { Chi-square } \\
(\text { Prob }>\mid \text { Chi-sq } \mid)\end{array}$ & $\begin{array}{l}59.44 \\
(0.00) \\
\end{array}$ & $\begin{array}{l}59.44 \\
(0.00) \\
\end{array}$ & $\begin{array}{l}66.87 \\
(0.00) \\
\end{array}$ & $\begin{array}{l}66.88 \\
(0.00)\end{array}$ \\
\hline (Pseudo) R-sq & 0.2715 & 0.2715 & 0.2374 & 0.2375 \\
\hline $\mathrm{N}$ & 500 & 500 & 1093 & 1093 \\
\hline
\end{tabular}

Notes: 1. The values within parentheses are standard errors.

2. *, ** and $* * *$ indicate significance at the 1 percent, 5 percent and 10 percent levels respectively. 
Table 7

Determinants of Childbirth in 1992 (IV)

\begin{tabular}{|c|c|c|c|c|}
\hline & \multicolumn{2}{|c|}{ Specification 1} & \multicolumn{2}{|c|}{ Specification 2} \\
\hline & OLS IV & Tobit IV & OLS IV & Tobit IV \\
\hline AGE, AGESQ & Yes * & Yes * & Yes & Yes \\
\hline TREIM & Yes & Yes & Yes * & Yes * \\
\hline $\begin{array}{l}\text { MARRIED, KIDTIL92, } \\
\text { WHOUR (fitted), } \\
\text { PCARE, NOYEDU, } \\
\text { SIZOHH }\end{array}$ & Yes & Yes & Yes & Yes \\
\hline UNCRT3P & $\begin{aligned}- & 0.6361 \\
& (0.7291)\end{aligned}$ & $\begin{array}{r}-0.6361 \\
(0.7291)\end{array}$ & $\begin{array}{rl}-1 & 1.2618 \\
& (3.1857)\end{array}$ & $\begin{array}{l}-1.2629 \\
(3.1855)\end{array}$ \\
\hline UNCRT4P & $\begin{array}{c}-0.5210 \\
(0.5084)\end{array}$ & $\begin{array}{c}-0.5211 \\
(0.5083)\end{array}$ & $\begin{array}{c}-0.4891 \\
(2.5702)\end{array}$ & $\begin{array}{c}-0.4897 \\
(2.5700)\end{array}$ \\
\hline UNCRT5P & $\begin{array}{r}-0.3724 \\
(0.3586)\end{array}$ & $\begin{array}{r}-0.3723 \\
(0.3587)\end{array}$ & $\begin{aligned}- & 0.2155 \\
& (1.2478)\end{aligned}$ & $\begin{array}{c}-0.2151 \\
(1.2477)\end{array}$ \\
\hline UNCRT6P & $\begin{array}{c}-0.0472 \\
(0.2938)\end{array}$ & $\begin{array}{c}-0.0470 \\
(0.2959)\end{array}$ & $\begin{array}{l}1.5418 \\
(1.0044)\end{array}$ & $\begin{array}{l}1.5421 \\
(1.0044)\end{array}$ \\
\hline UNCRT3PSQ & & & $\begin{array}{l}0.1882 \\
(0.7144)\end{array}$ & $\begin{array}{l}0.1886 \\
(0.7144)\end{array}$ \\
\hline UNCRT4PSQ & & & $\begin{array}{c}-0.0986 \\
(0.6042)\end{array}$ & $\begin{array}{c}-0.0985 \\
(0.6041)\end{array}$ \\
\hline UNCRT5PSQ & & & $\begin{array}{l}0.0059 \\
(0.1987)\end{array}$ & $\begin{array}{l}0.0058 \\
(0.1987)\end{array}$ \\
\hline UNCRT6PSQ & & & $\begin{array}{c}-0.6002 * * \\
(0.3018)\end{array}$ & $\begin{array}{c}-0.6003 * * \\
(0.3018)\end{array}$ \\
\hline TREIM*UNCRT3P & $\begin{array}{l}0.0104 \\
(0.0192)\end{array}$ & $\begin{array}{l}0.0104 \\
(0.0192)\end{array}$ & & \\
\hline TREIM*UNCRT4P & $\begin{array}{c}-0.0333 * * * \\
(0.0171)\end{array}$ & $\begin{array}{c}-0.0333 * * * \\
(0.0171)\end{array}$ & & \\
\hline TREIM*UNCRT5P & $\begin{array}{l}0.0133 \\
(0.0111)\end{array}$ & $\begin{array}{l}0.0133 \\
(0.0111)\end{array}$ & & \\
\hline TREIM*UNCRT6P & $\begin{array}{r}-0.0054 \\
(0.0119)\end{array}$ & $\begin{array}{c}-0.0054 \\
(0.0119)\end{array}$ & & \\
\hline $\begin{array}{l}\text { Chi-square } \\
(\text { Prob }>\mid \text { Chi-sq } \mid)\end{array}$ & $\begin{array}{l}101.77 \\
(0.0000)\end{array}$ & $\begin{array}{l}101.80 \\
(0.0000)\end{array}$ & $\begin{array}{l}66.68 \\
(0.0000)\end{array}$ & $\begin{array}{l}66.72 \\
(0.0000)\end{array}$ \\
\hline (Pseudo) R-sq & 0.2870 & 0.2870 & 0.2886 & 0.2885 \\
\hline $\mathrm{N}$ & 537 & 537 & 537 & 537 \\
\hline
\end{tabular}

Notes: 1. The values within parentheses are standard errors.

2. *, ** and $* * *$ indicate significance at the 1 percent, 5 percent and 10 percent levels respectively. 
Table 8

Determinants of Childbirth in 1996 (IV)

\begin{tabular}{|c|c|c|c|c|}
\hline & \multicolumn{2}{|c|}{ Specification 1} & \multicolumn{2}{|c|}{ Specification 2} \\
\hline & OLS IV & Tobit IV & OLS IV & Tobit IV \\
\hline $\begin{array}{l}\text { AGE, AGESQ, } \\
\text { KIDTIL96, TREIM, } \\
\text { NOYEDU, SIZOHH }\end{array}$ & Yes * & Yes * & Yes * & Yes * \\
\hline $\begin{array}{l}\text { MARRIED, WHOUR } \\
\text { (fitted), PCARE, } \\
\text { SECARE, SPCARE, } \\
\text { SESTAT, LIQAST }\end{array}$ & Yes & Yes & Yes & Yes \\
\hline UNCRT1P & $\begin{array}{l}0.1949 \\
(0.2910)\end{array}$ & $\begin{array}{l}0.1961 \\
(0.2654)\end{array}$ & $\begin{array}{l}-0.2223 \\
(1.0044)\end{array}$ & $\begin{array}{l}-0.2226 \\
(1.0047)\end{array}$ \\
\hline UNCRT2P & $\begin{array}{l}0.0448 \\
(0.2217)\end{array}$ & $\begin{array}{l}0.0450 \\
(0.2240)\end{array}$ & $\begin{array}{l}0.7951 \\
(0.8089)\end{array}$ & $\begin{array}{l}0.7968 \\
(0.8091)\end{array}$ \\
\hline UNCRT3P & $\begin{array}{r}-0.1880 \\
(0.3231)\end{array}$ & $\begin{array}{r}-0.1878 \\
(0.3118)\end{array}$ & $\begin{array}{l}1.7493 \\
(1.5177)\end{array}$ & $\begin{array}{l}1.7471 \\
(1.5180)\end{array}$ \\
\hline UNCRT4P & $\begin{array}{l}0.3272 \\
(0.3192)\end{array}$ & $\begin{array}{l}0.3253 \\
(0.2668)\end{array}$ & $\begin{array}{l}4.2195 * \\
(1.3167)\end{array}$ & $\begin{array}{l}4.2245^{*} \\
(1.3168)\end{array}$ \\
\hline UNCRT5P & $\begin{array}{c}-0.1731 * * * \\
(0.1064)\end{array}$ & $\begin{array}{c}-0.1736^{* * * *} \\
(0.1006)\end{array}$ & $\begin{array}{c}-0.7691 * * * \\
(0.4577)\end{array}$ & $\begin{array}{c}-0.7670 * * * \\
(0.4578)\end{array}$ \\
\hline UNCRT6P & $\begin{array}{l}0.2623 \\
(0.1859)\end{array}$ & $\begin{array}{l}0.2623 \\
(0.2058)\end{array}$ & $\begin{array}{c}-0.4244 \\
(0.5114)\end{array}$ & $\begin{array}{l}-0.4275 \\
(0.5115)\end{array}$ \\
\hline UNCRT1PSQ & & & $\begin{array}{l}0.0143 \\
(0.2379)\end{array}$ & $\begin{array}{l}0.0146 \\
(0.2380)\end{array}$ \\
\hline UNCRT2PSQ & & & $\begin{array}{c}-0.1672 \\
(0.1876)\end{array}$ & $\begin{array}{c}-0.1678 \\
(0.1876)\end{array}$ \\
\hline UNCRT3PSQ & & & $\begin{array}{c}-0.4174 \\
(0.3445)\end{array}$ & $\begin{array}{r}-0.4167 \\
(0.3446)\end{array}$ \\
\hline UNCRT4PSQ & & & $\begin{array}{r}-1.0106^{*} \\
(0.3161)\end{array}$ & $\begin{array}{r}-1.0121^{*} \\
(0.3162)\end{array}$ \\
\hline UNCRT5PSQ & & & $\begin{array}{l}0.0981 \\
(0.0699)\end{array}$ & $\begin{array}{l}0.0977 \\
(0.0699)\end{array}$ \\
\hline UNCRT6PSQ & & & $\begin{array}{l}0.2511 \\
(0.1687)\end{array}$ & $\begin{array}{l}0.2519 \\
(0.1688)\end{array}$ \\
\hline TREIM*UNCRT1P & $\begin{array}{c}-0.0233 * * * \\
(0.0119)\end{array}$ & $\begin{array}{c}-0.0238 * * * \\
(0.0130)\end{array}$ & & \\
\hline TREIM*UNCRT2P & $\begin{array}{l}0.0010 \\
(0.0089)\end{array}$ & $\begin{array}{l}0.0010 \\
(0.0101)\end{array}$ & & \\
\hline TREIM*UNCRT3P & $\begin{array}{l}0.0074 \\
(0.0143)\end{array}$ & $\begin{array}{l}0.0074 \\
(0.0154)\end{array}$ & & \\
\hline TREIM*UNCRT4P & $\begin{array}{r}-0.0042 \\
(0.0129)\end{array}$ & $\begin{array}{c}-0.0041 \\
(0.0127)\end{array}$ & & \\
\hline TREIM*UNCRT5P & $\begin{array}{c}-0.0046 \\
(0.0076)\end{array}$ & $\begin{array}{c}-0.0045 \\
(0.0127)\end{array}$ & & \\
\hline TREIM*UNCRT6P & $\begin{array}{c}-0.0096 \\
(0.0076)\end{array}$ & $\begin{array}{c}-0.0047 \\
(0.0097)\end{array}$ & & \\
\hline $\begin{array}{l}\text { Chi-square } \\
(\text { Prob > |Chi-sq } \mid)\end{array}$ & $\begin{array}{l}129.65 \\
(0.0000)\end{array}$ & $\begin{array}{l}93.02 \\
(0.0000)\end{array}$ & $\begin{array}{l}140.56 \\
(0.0000)\end{array}$ & $\begin{array}{l}140.74 \\
(0.0000)\end{array}$ \\
\hline (Pseudo) R-sq & 0.2519 & 0.2522 & 0.2730 & 0.2734 \\
\hline $\mathrm{N}$ & 1093 & 1093 & 1093 & 1093 \\
\hline
\end{tabular}

Notes: 1 . The values within parentheses are standard errors.

2. *, ** and *** indicate significance at the 1 percent, 5 percent and 10 percent levels respectively. 